BNL-112050-2016-JA

\title{
Synchrotron study of metal localization in Typha latifolia L. root sections
}

\author{
Yu Qian, Huan Feng, Frank J. Gallagher, \\ Qingzhi Zhu, Meiyin Wu, Chang-Jun Liu, \\ Keith W. Jones, and Ryan V. Tappero
}

Submitted to the Journal of Synchrotron Radiation

September 2015

\author{
Environmental And Climate Sciences Department \\ Brookhaven National Laboratory
}

\author{
U.S. Department of Energy \\ USDOE Office of Science (SC), \\ Basic Energy Sciences (BES) (SC-22)
}

Notice: This manuscript has been authored by employees of Brookhaven Science Associates, LLC under Contract No. DE- SC0012704 with the U.S. Department of Energy. The publisher by accepting the manuscript for publication acknowledges that the United States Government retains a non-exclusive, paid-up, irrevocable, world-wide license to publish or reproduce the published form of this manuscript, or allow others to do so, for United States Government purposes. 


\section{DISCLAIMER}

This report was prepared as an account of work sponsored by an agency of the United States Government. Neither the United States Government nor any agency thereof, nor any of their employees, nor any of their contractors, subcontractors, or their employees, makes any warranty, express or implied, or assumes any legal liability or responsibility for the accuracy, completeness, or any third party's use or the results of such use of any information, apparatus, product, or process disclosed, or represents that its use would not infringe privately owned rights. Reference herein to any specific commercial product, process, or service by trade name, trademark, manufacturer, or otherwise, does not necessarily constitute or imply its endorsement, recommendation, or favoring by the United States Government or any agency thereof or its contractors or subcontractors. The views and opinions of authors expressed herein do not necessarily state or reflect those of the United States Government or any agency thereof. 


\title{
Synchrotron study of metal localization in Typha latifolia L. root sections
}

\author{
Yu Qian, ${ }^{a} \neq$ Huan Feng, ${ }^{a} *$ Frank J. Gallagher, ${ }^{b}$ Qingzhi Zhu, ${ }^{c}$ Meiyin $\mathrm{Wu}{ }^{d}$ \\ Chang-Jun Liu, ${ }^{e}$ Keith W. Jones ${ }^{f}$ and Ryan V. Tappero ${ }^{f}$
}

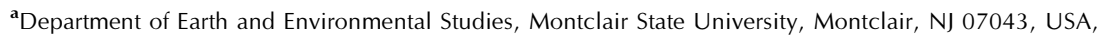

${ }^{\mathbf{b}}$ Environmental Planning and Design Program, Department of Landscape Architecture, Rutgers, The State University of New Jersey, New Brunswick, NJ 08901, USA, 'School of Marine and Atmospheric Science, State University of New York, Stony Brook, NY 11794, USA, dDepartment of Biology and Molecular Biology, Montclair State University, Montclair, NJ 07043, USA, ${ }^{\mathbf{e} B i o s c i e n c e s ~ D e p a r t m e n t, ~ B r o o k h a v e n ~ N a t i o n a l ~ L a b o r a t o r y, ~ U p t o n, ~ N Y ~ 11973, ~ U S A, ~ a n d ~}$ fPhoton Sciences Directorate, Brookhaven National Laboratory, Upton, NY 11973, USA.

*Correspondence e-mail: fengh@mail.montclair.edu

₹ Current Address: School of Ecology and Environmental Sciences, Yunnan University, Kunming, Yunnan 650091, People's Republic of China.

Keywords: synchrotron $\mu \mathrm{XRF}$; root metal uptake and transportation; iron plaque; Typha latifolia L.; wetland.

Supporting information: this article has supporting information at journals.iucr.org/s

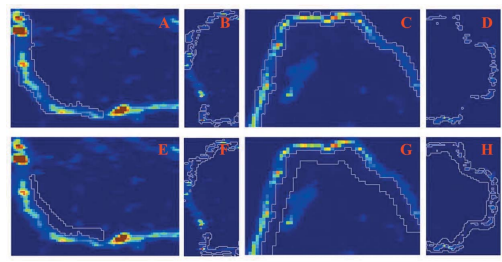

Understanding mechanisms that control plant root metal assimilation in soil is critical to the sustainable management of metal-contaminated land. With the assistance of the synchrotron X-ray fluorescence technique, this study investigated possible mechanisms that control the localization of $\mathrm{Fe}, \mathrm{Cu}, \mathrm{Mn}, \mathrm{Pb}$ and $\mathrm{Zn}$ in the root tissues of Typha latifolia $\mathrm{L}$. collected from a contaminated wetland. Metal localizations especially in the case of $\mathrm{Fe}$ and $\mathrm{Pb}$ in the dermal tissue and the vascular bundles were different. Cluster analysis was performed to divide the dermal tissue into iron-plaque-enriched dermal tissue and regular dermal tissue based on the spatial distribution of $\mathrm{Pb}$ and $\mathrm{Fe}$. Factor analysis showed that $\mathrm{Cu}$ and $\mathrm{Zn}$ were closely correlated to each other in the dermal tissues. The association of $\mathrm{Cu}, \mathrm{Zn}$ and $\mathrm{Mn}$ with $\mathrm{Fe}$ was strong in both regular dermal tissue and iron-plaque-enriched dermal tissue, while significant $(p<$ 0.05 ) correlation of $\mathrm{Fe}$ with $\mathrm{Pb}$ was only observed in tissues enriched with iron plaque. In the vascular bundles, $\mathrm{Zn}, \mathrm{Mn}$ and $\mathrm{Cu}$ showed strong association, suggesting that the localization of these three elements was controlled by a similar mechanism. Iron plaque in the peripheral dermal tissues acted as a barrier for $\mathrm{Pb}$ and a buffer for $\mathrm{Zn}, \mathrm{Cu}$ and $\mathrm{Mn}$. The Casparian strip regulated the transportation of metals from dermal tissues to the vascular bundles. The results suggested that the mechanisms controlling metal localization in root tissues varied with both tissue types and metals.

\section{Introduction}

Urban soil contamination has increased dramatically in recent decades due to anthropogenic activities (Qian et al., 2011; Wuana \& Okieimen, 2011; Desouki \& Feng, 2012; Luo et al., 2012). Lead ( $\mathrm{Pb})$, copper $(\mathrm{Cu})$, manganese $(\mathrm{Mn})$ and zinc $(\mathrm{Zn})$ are contaminants commonly find in urban soil. Once they enter the soil, these metals cannot be degraded and tend to accumulate in the soil and pose potential risks to urban ecological stability and human health. Urban brownfields are a concern specifically because they are in densely populated areas and difficult to revitalize (French et al., 2006; Gallagher et al., 2008; Luo et al., 2012). Plants are transplanted in abandoned brownfields to mitigate soil metal contamination, improve urban ecosystem stability and remediate soil metal contamination (McKenna, 1998; French et al., 2006; Dickinson et al., 2009; Desouki \& Feng, 2012;). Typha latifolia L. (broadleaf cattail) is a wetland plant that is widely used for 
wetland restoration, eutrophic lake clean-up and wastewater effluent treatment (Ye et al., 1997, 1998; Sasmaz et al., 2008; Calheiros et al., 2009). Previous field studies identified T. latifolia $\mathrm{L}$. as a plant species that is capable of tolerating soil with extremely high metal concentration (McNaughton et al., 1974), which makes it an ideal candidate for metal phytoextraction from the contaminated wetlands to meet remediation purpose (McNaughton et al., 1974; Ye et al., 1997, 2001; Sasmaz et al., 2008; Brunham \& Bendell, 2010; Grisey et al., 2012; Klink et al., 2012). A better understanding of metal uptake and translocation processes in the plant will benefit future application of $T$. latifolia $L$. in environmental management projects.

The uptake and translocation of metals by plant root is controlled by many mechanisms that vary with root tissues. On the surface of wetland plant root, a layer of amorphous Fe hydroxide named as iron plaque is commonly observed (Ye et $a l ., 1997)$. The negative surface charge of iron plaque makes it capable of adsorbing or co-precipitating metal(loid)s (Ye et al., 1998, 2001). Located at the interface between soil pore water and root surface dermal tissues, iron plaque plays a role either as a buffer that enhances metal uptake efficiency or as a barrier that restricts the transportation of metals at the root surface (Tripathi et al., 2014). On the peripheral part of the root are dermal tissues, which either uptake metal ions in soil pore water freely through passive diffusion in the apoplast system or uptake and transport metals selectively into the symplast system under the assistance of selective cell membrane transporters (Taiz \& Zeiger, 2010; Marschner, 2012). When metals reach the vascular bundles in the middle of the root, the transportation of substances in the apoplast is blocked by the Casparian strip and prevents them from entering the vascular bundles. Only metals in the symplastic system can enter the vascular tissue and be further transported to the plant shoot (Brennan \& Shelley, 1999; Clemens \& Palmgren, 2002; Rascio \& Navari-Izzo, 2011). Localization of metals in root tissues indicates the possible mechanisms a plant root takes to regulate metal uptake and transportation processes (Marschner, 2012).

Recently, advanced high-resolution analytical techniques have provided micro-scale metal localization information and supported plant metal uptake and translocation mechanisms studies. For example, Lyubenova et al. (2012, 2013) applied micro-proton-induced X-ray emission (micro-PIXE) to analyze the spatial distribution of 18 elements in T. latifolia L. tissues and observed tissue-specific distribution patterns of these elements. Synchrotron X-ray absorption near-edge microstructure spectroscopy (XANES) measurement for identification of $\mathrm{Pb}$ and $\mathrm{Fe}$ speciation on T. latifolia $\mathrm{L}$. roots surface showed that $\mathrm{Pb}(\mathrm{II})$ and $\mathrm{Fe}(\mathrm{III})$ are the major species in the iron plaque in the root epidermis (Feng et al., 2013). In this study, we aimed to investigate the mechanisms that control the localization of $\mathrm{Cu}, \mathrm{Fe}, \mathrm{Pb}, \mathrm{Mn}$ and $\mathrm{Zn}$ in T. latifolia L. root tissues and understand uptake and translocation mechanisms in T. latifolia L. root for metal assimilation.

\section{Methodology}

\subsection{Study site}

The study area was chosen in an urban brownfield within Liberty State Park, New Jersey, USA, with an area of $1 \mathrm{~km}^{2}$. This region was once used for railway transportation and coal storage for a century. As a result of previous industrial activities, high soil metal concentrations were found in this area (Gallagher et al., 2008; Qian et al., 2012). The specific site for this study was chosen at a wetland site which is part of a storm water drainage ditch. Previous studies showed that the total soil metal concentrations of $\mathrm{Cu}, \mathrm{Pb}$ and $\mathrm{Zn}$ in this wetland were $124 \pm 51 \mu \mathrm{g} \mathrm{g}^{-1}, 453 \pm 266 \mu \mathrm{g} \mathrm{g}^{-1}$ and $309 \pm$ $125 \mu \mathrm{g} \mathrm{g}^{-1}$, respectively, which were all above the background levels in New Jersey (Cu: $14 \mu \mathrm{g} \mathrm{g}^{-1}$; Pb: $35 \mu \mathrm{g} \mathrm{g}^{-1} ; \mathrm{Zn}: 22 \mu \mathrm{g}$ $\mathrm{g}^{-1}$; EPA, 2005) and indicated the site was highly contaminated (Gallagher et al., 2008).

\subsection{Sample collection and process}

Because plants in the growing season have the highest metabolism rate and root-to-shoot translocation rate, this period is selected to conduct root metal uptake/translocation mechanism study. The growing season of $T$. latifolia L. usually lasts from May to July each year (Tursun et al., 2011). Plant samples were collected from the study site in the growing season in 2010 and 2011 along the edge of a storm water drainage ditch. After collection, the samples were immediately transported to Montclair State University for laboratory treatment. Bulk soils on the plant roots were removed by hand initially, then the soil particles were rinsed off gently with tap water and finally with distilled-deionized water. To prepare the samples for synchrotron X-ray fluorescence (XRF) analysis, fresh roots were excised from the plant and then embedded in the cryo-embedding compound and then frozen to a solid at an optimal cutting temperature of $253 \mathrm{~K}$ (Feng et al., 2013). The root sections of $30 \mu \mathrm{m}$ thickness were then cut from the frozen samples with a cryotome (Cryostat CM1950, Leica Microsystems) and mounted on a $25 \mathrm{~mm} \times 76 \mathrm{~mm}$ quartz microscope slide (SPI Supplies ${ }^{\mathbb{R}}$ ). Two root sections were prepared from one plant collected in each year. Four root sections were made in total. The prepared root sections were stored at $277 \mathrm{~K}$ before synchrotron XRF analysis (Zhang et al., 2011).

\subsection{Synchrotron analysis}

Synchrotron micro X-ray fluorescence ( $\mu \mathrm{XRF}$ ) analysis on the four root sections was conducted at the X27A beamline workstation at the National Synchrotron Light Source at Brookhaven National Laboratory (Upton, NY, USA). The energy range was fixed at $13.5 \mathrm{keV}$ to excite fluoresces of $\mathrm{Cu}$, $\mathrm{Fe}, \mathrm{Pb}, \mathrm{Mn}$ and $\mathrm{Zn}$ simultaneously. Optical images of the root sections were collected with an optical microscope before synchrotron XRF analysis. Before the analysis started, the slide mounted with the samples was oriented at $45^{\circ}$ to the beam and a 13-element Canberra Ge array was used to 

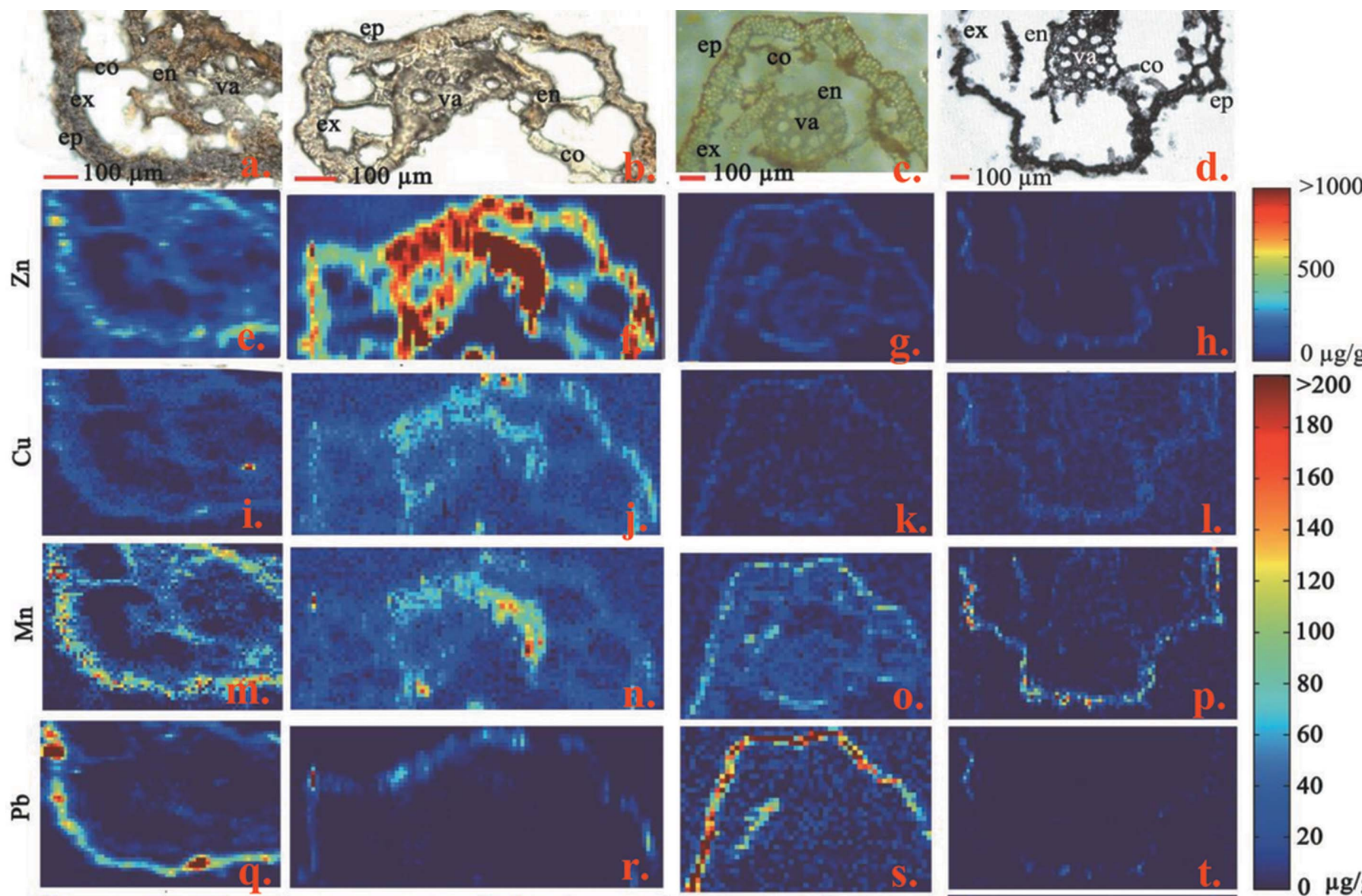

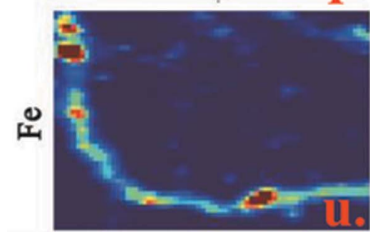

Near the root tip

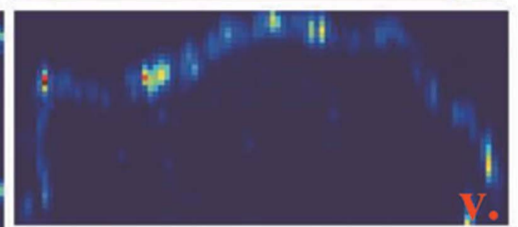

In the the middle of root

T. latifolia L. collected in June 2010
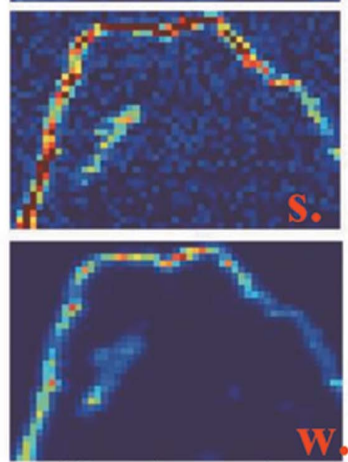

Near the root tip
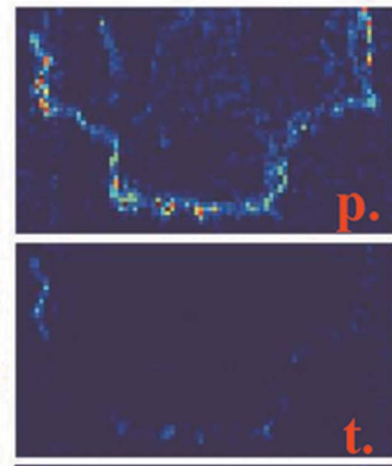

$-160$

140

120

100

80

60

40

20

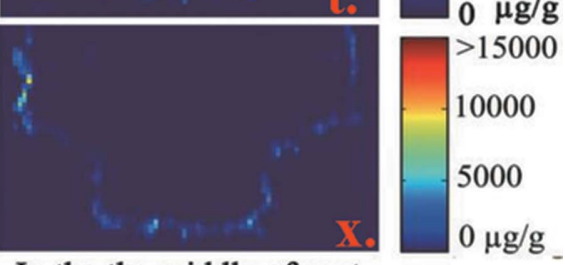

In the the middle of root

T. latifolia L. collected in May 2011

Figure 1

Optical images and concentration $\left(\mu \mathrm{g} \mathrm{g}^{-1}\right)$ spatial distribution of $\mathrm{Cu}, \mathrm{Mn}, \mathrm{Pb}, \mathrm{Fe}$ and $\mathrm{Zn}$ in T. latifolia $\mathrm{L}$. root sections in the tip and the middle of roots collected in 2010 and 2011. ep: epidermis; ex: exodermis; co: cortex; en: endodermis; ca: Casparian strip; va: vascular tissues [ $(a)-(d)$ optical images of root tissue sections; $(e)-(h)$ spatial distribution of $\mathrm{Zn} ;(i)-(l)$ spatial distribution of $\mathrm{Cu} ;(m)-(p)$ spatial distribution of $\mathrm{Mn} ;(q)-(t)$ spatial distribution of $\mathrm{Pb} ;(u)-(x)$ spatial distribution of $\mathrm{Fe}]$

collect an elemental map with a step size of $10 \mu \mathrm{m}$ and a dwell time of $7 \mathrm{~s}$ (Fig. 1). The synchrotron XRF data collection was carried out at the beamline workstation and then processed at Montclair State University. NIST Standard Reference Material (SRM) 1832 and 1833 were analyzed along with the samples during each synchrotron XRF measurement.

Longitudinal mapping of metal $(\mathrm{Cu}, \mathrm{Fe}, \mathrm{Mn}$ and $\mathrm{Zn})$ distributions in the root specimens was carried out at the NSLS X26A beamline using a synchrotron $\mu$ XRF microprobe. The X-ray energy was set at $13.5 \mathrm{keV}$. The beam size on the sample was $7 \mu \mathrm{m} \times 10 \mu \mathrm{m}$ with a step size of $15 \mu \mathrm{m}$. The attenuation of the incident $\mathrm{X}$-rays and outgoing X-rays was relatively low so that the entire thickness of the root was sampled with varying efficiencies.

\subsection{Root anatomy}

Five different types of root tissue could be identified based on optical images of the root section: epidermis, exodermis, cortex, endodermis and vascular bundles [Figs. 1(a)-1(d)].

\subsection{Data processing and analysis}

2.5.1. Tissue data extraction. The original micro-scale concentration data of metals $(\mathrm{Cu}, \mathrm{Zn}, \mathrm{Mn}, \mathrm{Pb}$ and $\mathrm{Zn})$ in each root section was saved as a matrix and presented as a twodimensional map (Fig. 1). Each pixel in the synchrotron XRF map represents metal concentration in the root section voxel with a resolution of $10 \mu \mathrm{m} \times 10 \mu \mathrm{m}$ for the 2010 samples or $20 \mu \mathrm{m} \times 20 \mu \mathrm{m}$ for the 2011 samples. Based on root anatomy morphology observed in the optical images, the root dermal 
tissues and the vascular bundles (surrounded by endodermis) were identified (see Fig. S1 of the supporting information) and the data were extracted from the original XRF map using MATLAB (The MathWorks Inc., version 7.1.0.246). The extracted matrix data were then transformed into linear form for further statistical analysis.

2.5.2. Identification of iron-plaqueenriched root dermal tissues. Many studies have proved that iron plaque exists in peripheral dermal tissues and it can effectively adsorb metals such as $\mathrm{Pb}$, $\mathrm{Mn}, \mathrm{Zn}$ and $\mathrm{Cu}$ (Greipsson \& Crowder, 1992; St-Cyr \& Campbell, 1996; Ye et al., 1997). Iron plaque and regular dermal tissue accumulate metals through
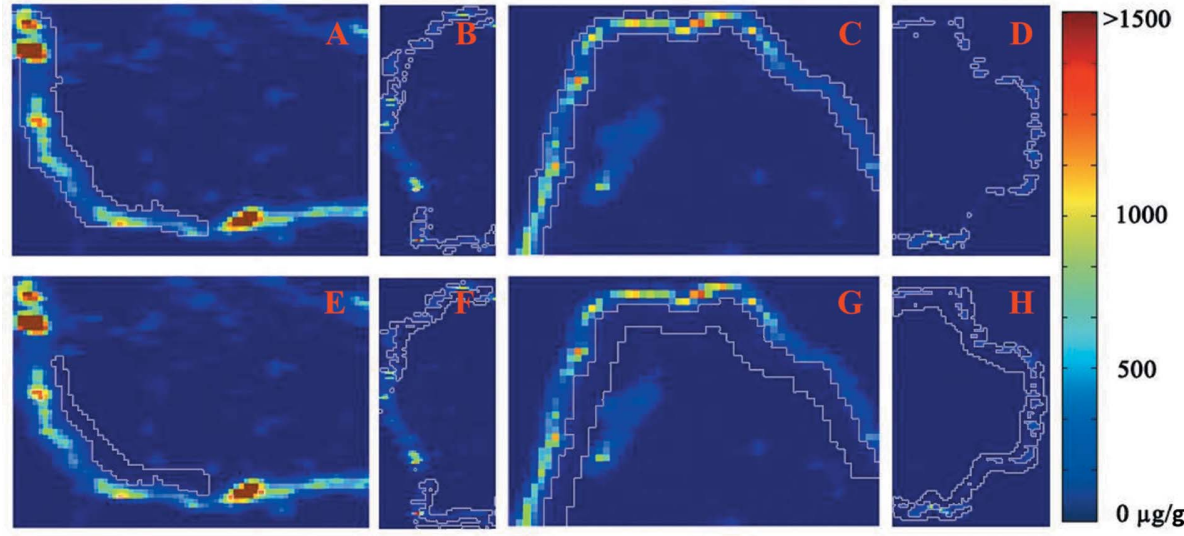

Figure 2

Iron plaque region and regular dermal tissue region identified by cluster analysis in the dermal tissues of four root sections [ $(a)-(d)$ CA1 iron plaque region; $(e)-(h)$ CA2 regular dermal tissue]. The concentration scale bar indicates the concentration of Fe in the XRF map; the regions traced by the white line indicate identified clusters.

different mechanisms. Therefore, it is

critical to separate the iron-plaque-enriched dermal tissues from regular dermal tissues in peripheral dermal tissues before analyzing the relationship between the metals.

High sorption of $\mathrm{Pb}$ by iron plaque on Iris pseudacorus L. root surface has already been reported (Zhong et al., 2010). Liu et al. (2011) also indicate that iron plaque can increase the sequestration of $\mathrm{Pb}$ on Oryza sativa $\mathrm{L}$. root surface. The similar spatial distribution of high concentration of $\mathrm{Pb}$ [Figs. $1(q)-1(t)$ ] and Fe [Figs. $1(u)-1(x)$ ] in T. latifolia L. dermal tissues is consistent with the observation in the above studies that there is strong association between $\mathrm{Pb}$ and iron plaque. Therefore, spatial distributions of $\mathrm{Pb}$ and $\mathrm{Fe}$ in the dermal tissue were used as an indicator of the existence of iron plaque in the dermal tissue.

Hierarchical cluster analysis was performed based on the spatial distributions of $\mathrm{Pb}$ and $\mathrm{Fe}$ in dermal tissues of each sample to investigate the close association between metal distributions in the dermal tissues and identify dermal tissue regions enriched in iron plaque. The type of joining algorithm used to amalgamate clusters was Ward's method and the metric for measuring the distance between the metals in each case was the Euclidean distance (Burns \& Burns, 2008; McDonald, 2009). Root dermal tissues are divided into two clusters: iron-plaque-enriched dermal tissues (in short, iron plaque) (CA1) and regular dermal tissues (CA2) (Fig. 2).

2.5.3. Data analysis. The metal concentration from synchrotron $\mu \mathrm{XRF}$ measurement was originally in units of counts per second (cps). It was then converted to units of $\mu \mathrm{g} \mathrm{g}^{-1}$ by calibrating the samples against the NIST SRM 1832 and 1833 thin glass film on polycarbonate for XRF spectrometry, provided that the root tissue density was $1.0 \mu \mathrm{g} \mathrm{g}^{-1}$. This calibration method did not account for differences in sample matrix and assumed that the absorption correction was not necessary, which works well for thin samples of uniform thickness (Feng et al., 2013, 2015). In statistical analysis, factor analysis was applied to identify the inherent association between the spatial distribution of $\mathrm{Cu}, \mathrm{Mn}, \mathrm{Fe}, \mathrm{Pb}$ and $\mathrm{Zn}$ in both dermal tissues and vascular bundles. Simple linear

regression analysis was performed to explore the relationship between metals. MATLAB, SYSTAT (SYSTAT Software Inc.) and JMP $\left(\mathrm{JMP}^{\mathrm{R}}\right)$ were applied for statistical analyses of the data.

\section{Result}

\subsection{Root anatomy analysis}

Fig. 1 shows the anatomy structure of root sections of T. latifolia L. Five different types of root tissue could be identified, which are epidermis, exodermis, cortex, endodermis and vascular bundles. Epidermis, exodermis and the tissue between are considered as dermal tissues [Fig. 1(a)-1(d), ep, ex]. Dermal tissue maintains the selectivity of root uptake from soil by taking up water and nutrients and avoiding unwanted compounds like toxic substances and soil-borne pathogens (Schreiber \& Franke, 2011). Cortex tissues include several layers of cells with thin cell walls [Fig. $1(a)-1(d)$, co]. In the middle of the root is a vascular bundle, surrounded by a layer of endodermis with the suberized Casparian strip [Fig. 1(a)-1(d), en and va]. The vascular bundles selectively transport substances from root cortex tissues and upload the substances to stems and shoots of the plant (Schreiber \& Franke, 2011).

\subsection{Metal localizations in dermal tissues and vascular bundles}

As indicated by the coefficient of variance for each element in Table 1, metal localization in root dermal tissues and vascular bundles are highly heterogeneous. Also, the concentration of one metal element in the same type of tissue from each sample is different (Fig. 1 and Table 1), suggesting that the accumulation of metals in root is inconsistent. Nevertheless, the spatial distribution pattern of metals is still very similar between the four samples (Fig. 1, ep, ex).

In the dermal tissues, the concentration of Fe is the highest among all of the five elements ranges from $374 \pm 836 \mu \mathrm{g} \mathrm{g}^{-1}$ to $3709 \pm 4806 \mu \mathrm{g} \mathrm{g}^{-1}$ (Table 1, Fig. 1). The coefficient of 
Table 1

Metal concentrations [mean \pm standard deviation (SD)] $\left(\mu \mathrm{g} \mathrm{g}^{-1}\right)$ and ranges (minimum, median, maximum) $\left(\mu \mathrm{g} \mathrm{g}^{-1}\right)$ of $\mathrm{Cu}, \mathrm{Fe}, \mathrm{Mn}, \mathrm{Pb}$ and $\mathrm{Zn}$ in the root sections collected in the tip and middle of T. latifolia L. in 2010 and 2011.

$\mathrm{BDL}=$ below detection limit.

\begin{tabular}{|c|c|c|c|c|c|c|c|c|c|c|c|c|c|}
\hline \multirow[b]{2}{*}{ Sample } & \multirow[b]{2}{*}{ Element } & \multicolumn{6}{|c|}{ Dermal tissues } & \multicolumn{6}{|c|}{ Vascular bundles } \\
\hline & & $n$ & $\begin{array}{l}\text { Min } \\
\left(\mu \mathrm{g} \mathrm{g}^{-1}\right)\end{array}$ & $\begin{array}{l}\operatorname{Max} \\
\left(\mu \mathrm{g} \mathrm{g}^{-1}\right)\end{array}$ & $\begin{array}{l}\text { Median } \\
\left(\mu \mathrm{g} \mathrm{g}^{-1}\right)\end{array}$ & $\begin{array}{l}\text { Mean } \\
\left(\mu \mathrm{g} \mathrm{g}^{-1}\right)\end{array}$ & c.v. & $n$ & $\begin{array}{l}\text { Min } \\
\left(\mu \mathrm{g} \mathrm{g}^{-1}\right)\end{array}$ & $\begin{array}{l}\operatorname{Max} \\
\left(\mu \mathrm{g} \mathrm{g}^{-1}\right)\end{array}$ & $\begin{array}{l}\text { Median } \\
\left(\mu \mathrm{g} \mathrm{g}^{-1}\right)\end{array}$ & $\begin{array}{l}\text { Mean } \\
\left(\mu \mathrm{g} \mathrm{g}^{-1}\right)\end{array}$ & c.v. \\
\hline \multirow[t]{4}{*}{2010 (I) } & $\mathrm{Fe} \dagger$ & & BDL & 33464 & 2373 & 3709 & 1.30 & & $\mathrm{BDL}$ & 1661 & 30.7 & 88.0 & 1.87 \\
\hline & $\mathrm{Zn} \dagger$ & 531 & 19.7 & 666 & 179 & 188 & 0.54 & \multirow[t]{3}{*}{836} & BDL & 453 & 73.7 & 104 & 0.78 \\
\hline & $\mathrm{Mn} \dagger$ & & BDL & 240 & 50.5 & 56.9 & 0.70 & & BDL & 138 & 15.9 & 25.7 & 1.07 \\
\hline & $\mathrm{Pb} \dagger$ & & BDL & 916 & 38.2 & 62.2 & 1.65 & & BDL & 30.6 & BDL & 2.22 & 2.05 \\
\hline \multirow{4}{*}{2010 (II) } & $\mathrm{Cu} \dagger$ & & 3.68 & 212 & 41.5 & 44.2 & 0.47 & \multirow{4}{*}{541} & $\mathrm{BDL}$ & 96.2 & 40.3 & 41.8 & 0.37 \\
\hline & $\mathrm{Zn} \dagger$ & 659 & 29.6 & 1466 & 468 & 510 & 0.51 & & BDL & 4027 & 742 & 964 & 0.69 \\
\hline & $\mathrm{Mn} \dagger$ & & 1.33 & 203 & 28.0 & 29.6 & 0.55 & & BDL & 199 & 38.9 & 50.8 & 0.67 \\
\hline & $\mathrm{Pb}^{\dagger}$ & & BDL & 422 & 3.01 & 9.63 & 2.86 & & BDL & 11.4 & BDL & 0.61 & 2.21 \\
\hline \multirow[t]{3}{*}{2011 (I) } & $\mathrm{Fe} \dagger$ & & 65.80 & 13821 & 349 & 1710 & 1.48 & & 55.8 & 1786 & 95.7 & 128 & 1.35 \\
\hline & $\mathrm{Cu}$ & & BDL & 43.3 & 3.17 & 4.45 & 1.17 & \multirow[b]{2}{*}{235} & BDL & 28.8 & 3.54 & 4.56 & 1.07 \\
\hline & $\mathrm{Zn}$ & 532 & BDL & 188 & 25.2 & 35.0 & 0.91 & & 0.77 & 192 & 31.6 & 38.3 & 0.84 \\
\hline \multirow{3}{*}{2011 (II) } & $\mathrm{Zn} \dagger$ & 880 & BDL & 252 & 14.2 & 23.7 & 1.26 & \multirow[t]{3}{*}{293} & BDL & 27.5 & 5.14 & 5.87 & 0.90 \\
\hline & $\mathrm{Mn} \dagger$ & & BDL & 259 & 8.89 & 22.4 & 1.52 & & BDL & 22.7 & BDL & 2.66 & 1.49 \\
\hline & $\mathrm{Pb} \dagger$ & & BDL & 70.0 & BDL & 1.86 & 3.47 & & BDL & 3.51 & BDL & 0.08 & 5.05 \\
\hline
\end{tabular}

$\dagger$ Significant difference between metal accumulation in the dermal tissue and the vascular bundle (Wilcoxon test, $p<0.05$ ).

variance (c.v.) of $\mathrm{Zn}, \mathrm{Cu}$ and $\mathrm{Mn}$ are all less than 1.3, much lower than that of $\mathrm{Fe}(1.30-2.24)$ and $\mathrm{Pb}(1.52-3.47)$. These results indicate that variations in $\mathrm{Zn}, \mathrm{Cu}$ and $\mathrm{Mn}$ distributions in the dermal tissue are less than that of $\mathrm{Fe}$ and $\mathrm{Pb}$ (Table 1); they also suggest that the localization of these two groups of element may be controlled by different mechanisms.

In the vascular bundles, the accumulations of the metals are different from that in the dermal tissue. The average concentration of $\mathrm{Zn}$ is the highest, ranging from $5.87 \pm 5.30 \mu \mathrm{g}$ $\mathrm{g}^{-1}$ to $964 \pm 666 \mu \mathrm{g} \mathrm{g}^{-1}$, followed by $\mathrm{Fe}$ $\left(9.82 \pm 5.55 \mu \mathrm{g} \mathrm{g}^{-1}\right.$ to $128 \pm 172 \mu \mathrm{g}$ $\left.\mathrm{g}^{-1}\right), \mathrm{Mn}\left(2.66 \pm 3.95 \mu \mathrm{g} \mathrm{g}^{-1}\right.$ to $50.8 \pm$ $\left.34.0 \mu \mathrm{g} \mathrm{g}^{-1}\right), \mathrm{Cu}\left(4.56 \pm 4.87 \mu \mathrm{g} \mathrm{g}^{-1}\right.$ to $\left.41.8 \pm 15.6 \mu \mathrm{g} \mathrm{g}^{-1}\right)$ and $\mathrm{Pb}(0.08 \pm$ $0.41 \mu \mathrm{g} \mathrm{g} \mathrm{g}^{-1}$ to $\left.6.20 \pm 7.82 \mu \mathrm{g} \mathrm{g} \mathrm{g}^{-1}\right)$ (Table 1). In particular, the concentrations of $\mathrm{Fe}$ and $\mathrm{Pb}$ in the vascular bundles are almost an order of magnitude lower than that in the dermal tissue, indicating that these two metals mainly accumulate in the dermal tissue of the root (Table 1, Fig. 1). As shown in Figs. $1(e)-1(p)$, bright rings of $\mathrm{Mn}, \mathrm{Cu}$ and $\mathrm{Zn}$ are observed around the vascular bundles, where the Casparian strip is likely located. In a study by Lyubenova et al. (2012), the same bright ring structure was observed in the root sections of $T$. latifolia $\mathrm{L}$. Therefore, the bright rings of $\mathrm{Mn}, \mathrm{Cu}$ and $\mathrm{Zn}$ around the vascular bundles observed in this study likely suggest apoplastic transportation and accumulation of $\mathrm{Mn}, \mathrm{Cu}$ and $\mathrm{Zn}$ around the Casparian strip. Synchrotron $\mu \mathrm{XRF}$ radiograph images (Fig. 3) show the heterogeneity of metal $(\mathrm{Cu}, \mathrm{Fe}, \mathrm{Mn}$ and $\mathrm{Zn}$ ) distribution along a $1 \mathrm{~cm}$-long root branch. Several 'hot spots' of metals are scattering across the branch. Therefore, heterogeneous distribution of metals could be observed not only across root sections but also along the axis of the root.
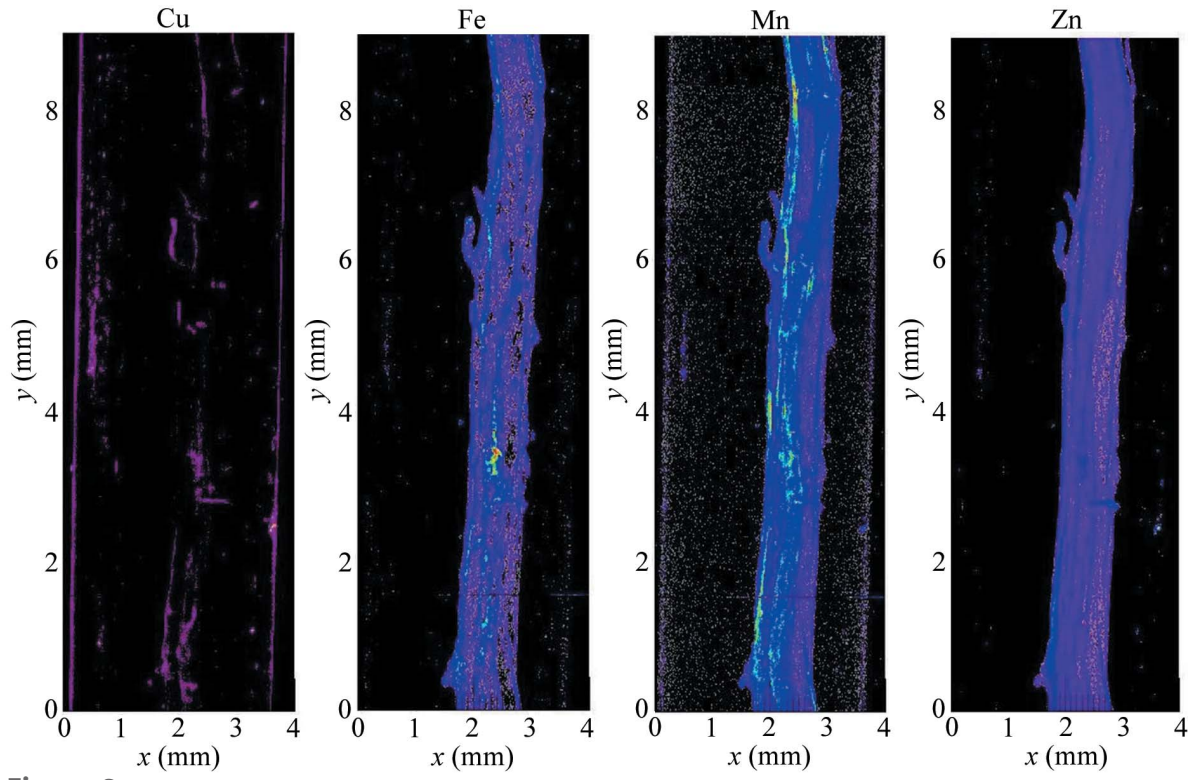

Spatial accumulation of $\mathrm{Cu}, \mathrm{Fe}, \mathrm{Mn}$ and $\mathrm{Zn}$ in the whole root collected in T. latifolia $\mathrm{L}$. in 2010 . 
Table 2

Results of factor analysis based on localization of $\mathrm{Cu}, \mathrm{Fe}, \mathrm{Mn}, \mathrm{Pb}$ and $\mathrm{Zn}$ in the dermal tissue and vascular bundle (rotated loading matrix, varimax rotation, gamma $=1.000$ ).

\begin{tabular}{|c|c|c|c|c|c|c|c|}
\hline \multicolumn{4}{|c|}{ Dermal tissues } & \multicolumn{4}{|c|}{ Vascular bundles } \\
\hline Parameter & Factor 1 & Factor 2 & Factor 3 & Parameter & Factor 1 & Factor 2 & Factor 3 \\
\hline $\log _{10}(\mathrm{Fe})$ & 0.95 & -0.07 & 0.13 & $\log _{10}(\mathrm{Zn})$ & 0.92 & -0.24 & 0.06 \\
\hline $\log _{10}(\mathrm{~Pb})$ & 0.91 & 0.17 & 0.22 & $\log _{10}(\mathrm{Mn})$ & 0.88 & 0.20 & 0.14 \\
\hline $\log _{10}(\mathrm{Cu})$ & 0.01 & 0.95 & 0.09 & $\log _{10}(\mathrm{Cu})$ & 0.87 & -0.22 & -0.01 \\
\hline $\log _{10}(\mathrm{Zn})$ & 0.08 & 0.93 & 0.14 & $\log _{10}(\mathrm{~Pb})$ & -0.12 & 0.97 & 0.15 \\
\hline $\log _{10}(\mathrm{Mn})$ & 0.25 & 0.18 & 0.95 & $\log _{10}(\mathrm{Fe})$ & 0.09 & 0.14 & 0.99 \\
\hline $\begin{array}{l}\% \text { of total } \\
\text { variance } \\
\text { explained }\end{array}$ & 35.7 & 36.4 & 20.0 & $\begin{array}{l}\% \text { of total } \\
\text { variance } \\
\text { explained }\end{array}$ & 47.9 & 21.9 & 20.3 \\
\hline
\end{tabular}

variance. It has high loadings of $\mathrm{Zn}$ (0.92), Mn (0.87) and $\mathrm{Cu}(0.87)$, which are all essential nutrients for plant growth. The other two factors have high loading of only one specific metal in each factor. Factor 2 has high loading of $\mathrm{Pb}(0.97)$ and explains $21.89 \%$ of the total variance. Factor 3 has high loading of $\mathrm{Fe}(0.99)$ and explains $20.32 \%$ of the total variance (Table 2). The factor analysis suggested that the accumulations of metals in the dermal tissues and the vascular bundles were controlled by different mechanisms.

\subsection{Relationship between the localization of metals in} dermal tissues and vascular bundles

Since the localization feature of metals is different between the dermal tissues and the vascular bundles (Fig. 1, Table 1), the mechanisms controlling the accumulation of metals in each tissue component should be examined. The association among $\mathrm{Pb}, \mathrm{Fe}, \mathrm{Mn}, \mathrm{Cu}$ and $\mathrm{Zn}$ in their spatial distributions in both dermal tissues and vascular bundles were analyzed in order to investigate possible mechanisms governing the uptake and transportation of metals. As shown in Table 1, the coefficients of variance of metal concentrations in the tissues are greater than 0.5 , suggesting a highly heterogeneous spatial accumulation of metals (Table 1). In order to reduce data skewness disturbing further statistical analysis, a logarithm $\left(\log _{10}\right)$ transformation was applied to all of the data (McDonald, 2009). In addition, all four root samples were collected in the growing season and they shared the same mechanisms in the regulation of root metal accumulations (Tursun et al., 2011). Therefore, the spatial distributions of $\mathrm{Pb}, \mathrm{Fe}, \mathrm{Mn}, \mathrm{Cu}$ and $\mathrm{Zn}$ from all four samples were analyzed together. Factor analysis was performed to explore the internal relationships between the metal spatial accumulation in both dermal tissues and vascular bundles.

In the dermal tissue, three factors with eigenvalue greater than 0.5 are identified, which explain $92 \%$ of the total variance (Table 2). High loadings of $\mathrm{Pb}(0.95)$ and $\mathrm{Fe}(0.91)$ are observed in Factor 1 that explains $35.73 \%$ of the total variance, indicating close relationship between $\mathrm{Pb}$ and $\mathrm{Fe}$ in their spatial distribution in the root dermal tissues. Sequestration of $\mathrm{Pb}$ on wetland plant root surface with iron plaque has been observed in many studies (e.g. Liu et al., 2007, 2011; Feng et al., 2013). Therefore, Factor 1 represents the iron plaque in the dermal tissues. Factor 2, which has high loadings of $\mathrm{Cu}(0.95)$ and $\mathrm{Zn}(0.93)$, explains $36.42 \%$ of the total variance. This factor indicates a close association between the distribution of $\mathrm{Zn}$ and $\mathrm{Cu}$ in the dermal tissue, possibly because both elements are essential nutrients. Factor 3 accounts for $20.00 \%$ of the total variance with only one high loading element, Mn (0.95).

In the vascular bundles, three factors with eigenvalue greater than 0.5 are identified and explain $90.14 \%$ of the total variance (Table 2). Factor 1 explains $47.93 \%$ of the total
In order to investigate the differences in metal localization mechanisms between the dermal tissues and the vascular bundles, the associations between the spatial distribution of $\mathrm{Cu}, \mathrm{Mn}, \mathrm{Pb}, \mathrm{Fe}$ and $\mathrm{Zn}$ in each type of tissue were further investigated. Simple linear regressions between the localization of metals in each specific type of root tissue were conducted to explore the association between metals.

\section{Discussion}

4.1. Effect of iron plaque on the spatial distributions of metals in dermal tissue

Because of the high affinity of metal cations to Fe hydroxide, iron plaque plays a role as either buffer or barrier of metals in the root uptake process. The role of iron plaque in the uptake of a metal can be judged based on the relationship between $\mathrm{Fe}$ and the metal in the iron plaque. If the correlation between $\mathrm{Fe}$ and the metal is strong in the iron plaque but weak in the regular dermal tissue, then iron plaque eliminates the uptake of this metal. If the correlation between $\mathrm{Fe}$ and the tissue, then iron plaque had no affinity to this metal. If the correlation between $\mathrm{Fe}$ and the metal was strong in both the iron plaque and the regular dermal tissue, it suggests that the iron plaque has strong affinity to the metal, but does not eliminate further transportation of the metal. In this case the iron plaque might be a buffer of the metal.

In this study a simple linear regression was applied to compare metal localization patterns $(\mathrm{Cu}, \mathrm{Mn}, \mathrm{Pb}$ and $\mathrm{Zn})$ between iron plaque and regular dermal tissues (Fig. 4). According to Fig. $4, \mathrm{~Pb}$ has significant $(p<0.05)$ positive correlation with $\mathrm{Fe}$ in the iron plaque in all four root samples [Figs. 4(a)-4(d)] with $r^{2}>0.5$, suggesting a significant correlation between $\mathrm{Fe}$ and $\mathrm{Pb}$ in the iron plaque. However, the association between $\mathrm{Fe}$ and $\mathrm{Pb}$ in regular dermal tissues is rather weak (Fig. 4). As shown in Table 3, the concentration of $\mathrm{Pb}$ is rather low in the inner rim of the dermal tissue. In addition, extremely low accumulation of $\mathrm{Pb}$ is observed in the cortex tissues and the vascular bundles in this study (Table 1, Fig. 1), indicating that a very limited amount of $\mathrm{Pb}$ was transported to the rest of the plant tissues. Very likely, iron plaque acts as a barrier for the uptake of $\mathrm{Pb}$ in T. latifolia $\mathrm{L}$. metal was weak in iron plaque but strong in regular dermal 
Table 3

Accumulation $\left(\mu \mathrm{g} \mathrm{g}^{-1}\right)$ of $\mathrm{Fe}$ in the iron plaque and regular dermal tissues from T. latifolia L. root sections collected in 2010 and 2011.

$\mathrm{BDL}=$ below detection limit.

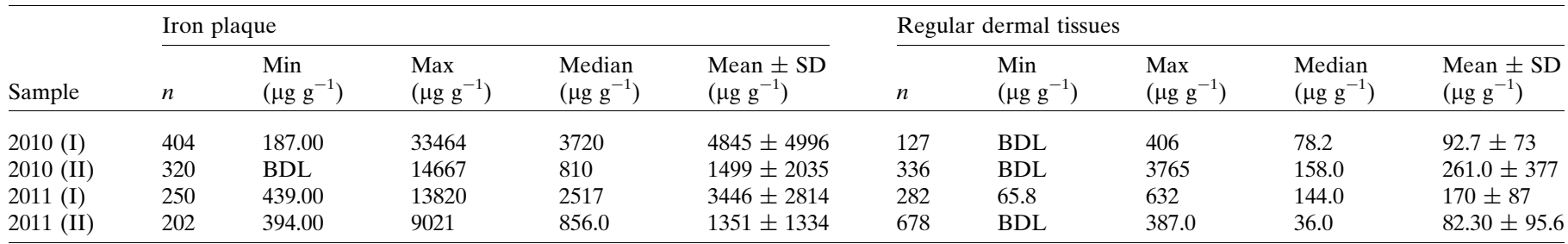

Similar to $\mathrm{Pb}$, the correlations between $\mathrm{Fe}$ and three essential elements $(\mathrm{Mn}, \mathrm{Zn}$ and $\mathrm{Cu})$ are significant $(p<0.05)$ in the iron plaque, indicating that iron plaque can co-precipitate these metals (Fig. 4). In the regular dermal tissues, however, the correlations of $\mathrm{Mn}, \mathrm{Zn}$ and $\mathrm{Cu}$ with $\mathrm{Fe}$ are inconsistent. Both significant [Fig. 4(e), 4(f), 4(h)-4(j), 4(l), $4(m)$ and $4(p)]$ and insignificant [Figs. $4(g), 4(k), 4(n)$ and $4(o)]$ correlations are observed. The results suggest that $\mathrm{Fe}$ and the three other metals $(\mathrm{Mn}, \mathrm{Zn}$ and $\mathrm{Cu}$ ) may not share the same transport and accumulation mechanisms in the regular dermal tissues.

The effect of iron plaque on the localization of $\mathrm{Cu}, \mathrm{Mn}$ and $\mathrm{Zn}$ in the root peripheral dermal tissue was further investigated by comparing the correlation among the three elements in the iron plaque and the regular dermal tissues (Fig. 5). Generally speaking, although the concentrations of
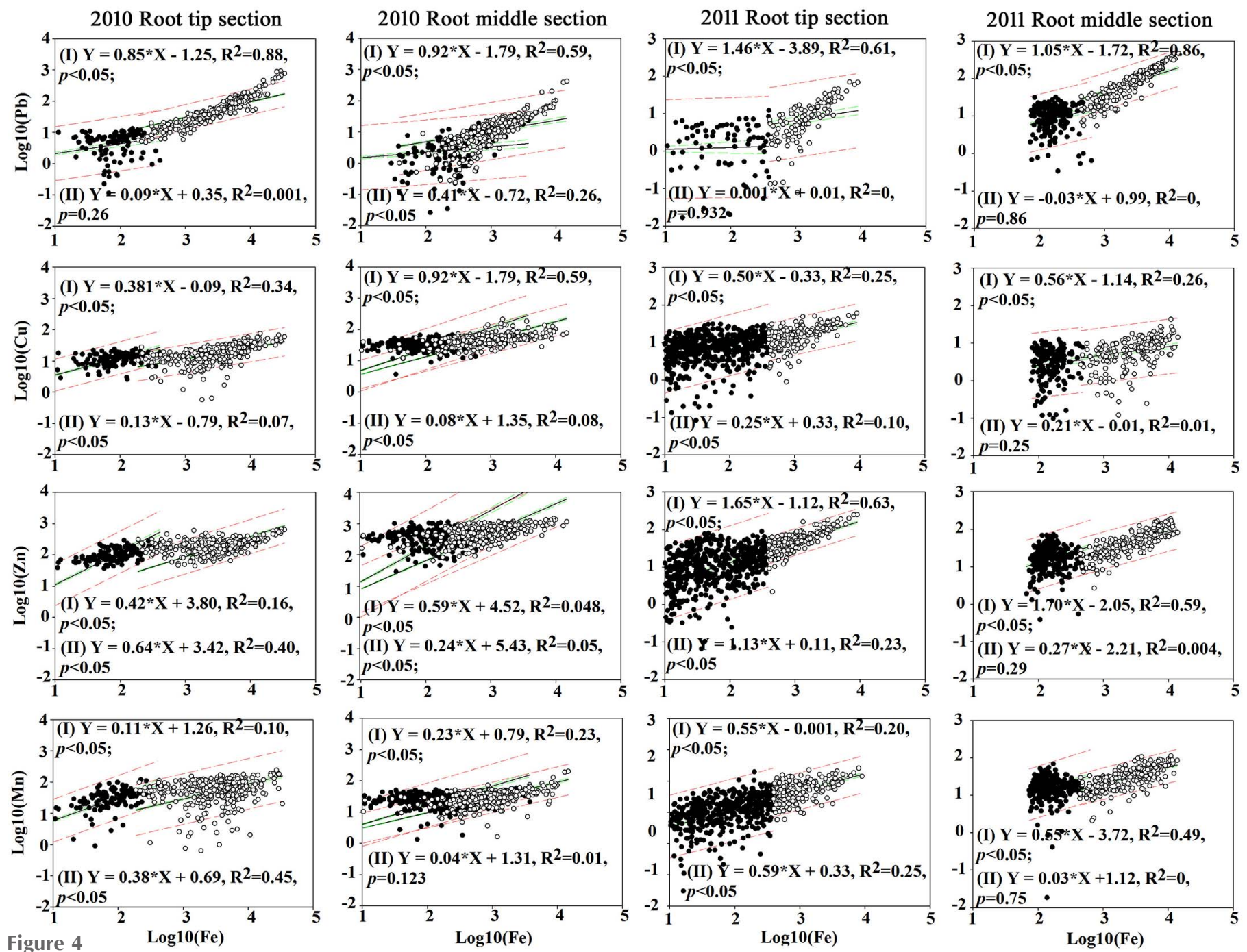

Linear regressions of $\mathrm{Pb}, \mathrm{Cu}, \mathrm{Zn}$ and $\mathrm{Mn}$ with $\mathrm{Fe}$ in the root tissue with iron plaque and the regular root dermal tissue. The T. latifolia $\mathrm{L}$. samples were collected in 2010 and 2011, respectively. Regression line (I) is for the dermal root tissue with Fe plaque, and regression line (II) is for the regular root dermal tissue. Filled circles: regular root dermal tissue. Open circles: root dermal tissue with Fe plaque. Black lines: linear regression lines. Green dashed lines: $95 \%$ confidence level. Red dashed lines: $95 \%$ prediction band. 
$\mathrm{Mn}, \mathrm{Zn}$ and $\mathrm{Cu}$ are higher in the iron plaque, there is no obvious difference in the associations between the three elements in the iron plaque and the regular dermal tissues (Fig. 5). The association of metals with cell wall is determined by the concentration of metal cations in soil solution and the competition between metal cations (Schreiber \& Franke, 2011). As shown in Fig. 5, the association between essential metals ( $\mathrm{Mn}, \mathrm{Fe}$ and $\mathrm{Cu}$ ) is similar no matter whether it is in iron plaque or in the regular dermal tissues, suggesting that the accumulations of these metals is possibly controlled by the same mechanism. The only difference is that iron plaque adsorbs more $\mathrm{Mn}, \mathrm{Zn}$ and $\mathrm{Cu}$, causing high accumulation of these metals within the Fe plaque. These observations are consistent with previous studies conducted by St-Cyr \& Campbell (1996) and Batty et al. (2000) who suggested that the adsorption and co-precipitation of $\mathrm{Cu}$, $\mathrm{Mn}$ and $\mathrm{Zn}$ with iron plaque should not influence the further root uptake of these metals. Therefore, iron plaque possibly acts as a buffer for the accumulation of $\mathrm{Mn}, \mathrm{Zn}$ and $\mathrm{Cu}$ in T. latifolia L.

\subsection{Spatial distributions of metals in vascular bundles}

Vascular bundles bridge the exchange of nutrients between roots and shoots and upload mineral nutrients from roots to shoots through xylem. In this study, high concentrations of $\mathrm{Zn}$,
$\mathrm{Mn}$ and $\mathrm{Cu}$ on the Casparian strip around the vascular bundles were observed (Fig. 1). Similar rings with high metal concentrations around the endodermis were also observed by Yamaguchi et al. (2011). They exposed Solanum torvum (Cd excluder) and Sloanum melongena (Cd accumulator) to a high concentration of $\mathrm{Cd}$ and found that the $\mathrm{Cd}$ concentration around the endodermis was higher in Solanum torvum than in Sloanum melongena (Yamaguchi et al., 2011). Therefore, it is possible that the Casparian strip in the root may delay the transportation of $\mathrm{Zn}, \mathrm{Mn}$ and $\mathrm{Cu}$ from apoplast to symplast.

In order to examine the similarity or difference in metal ( $\mathrm{Zn}, \mathrm{Mn}$ and $\mathrm{Cu}$ ) accumulation mechanisms between the dermal tissues and the vascular bundles, the correlations between $\mathrm{Zn}$ and $\mathrm{Mn}, \mathrm{Zn}$ and $\mathrm{Cu}$, and $\mathrm{Mn}$ and $\mathrm{Cu}$ in both types of tissue were compared (Fig. 6). Significant $(p<0.05)$ positive correlations were observed between $\mathrm{Mn}$ and $\mathrm{Zn}$, indicating the similar uptake and transport mechanisms between these two elements. In previous studies it was found that $\mathrm{Zn}$ and $\mathrm{Mn}$ could be taken up by $T$. latifolia L. from the rhizosphere soil more effectively than $\mathrm{Cu}$ (Sasmaz et al., 2008; Klink et al., 2012), and Mn and Zn usually shared the same transporters, such as ZIP and IRT1 in the root tissue (Hall \& Williams, 2003).

The slopes of the regression lines for metal correlations show nearly no difference between the dermal tissues and the vascular bundles in most cases (Fig. 6). Different trends in the
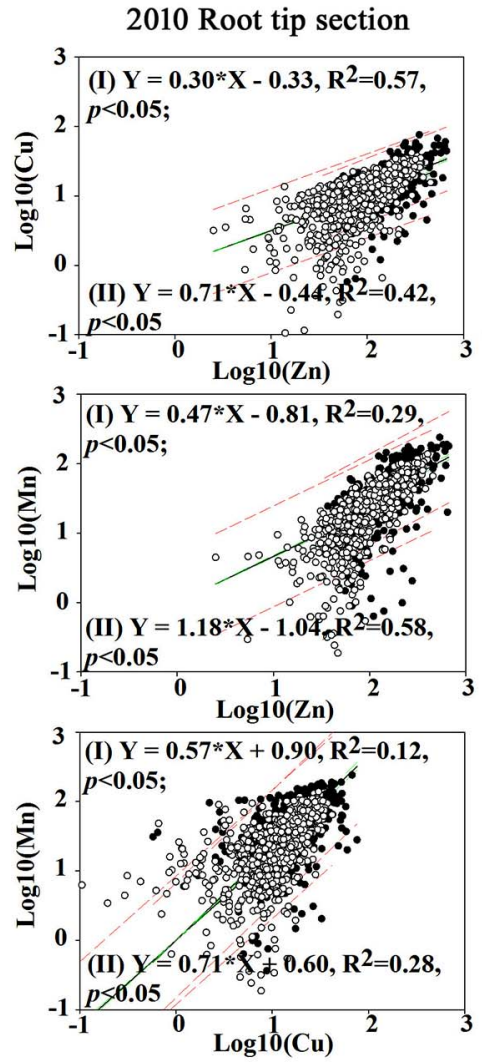

Figure 5

Linear regressions showing relationships between essential nutrients, i.e. $\mathrm{Cu}$ versus $\mathrm{Zn}, \mathrm{Mn}$ versus $\mathrm{Zn}$, and $\mathrm{Mn}$ versus $\mathrm{Cu}$, in the dermal tissue with Fe plaque and the regular dermal tissue. The T. latifolia L. samples were collected in 2010 and 2011, respectively. Regression line (I) is for the dermal root tissue with Fe plaque, and regression line (II) is for the regular root dermal tissue. Filled circles: regular root dermal tissue. Open circles: root dermal tissue with Fe plaque. Black lines: linear regression lines. Green dashed lines: 95\% confidence level. Red dashed lines: $95 \%$ prediction band.
2011 Root tip section
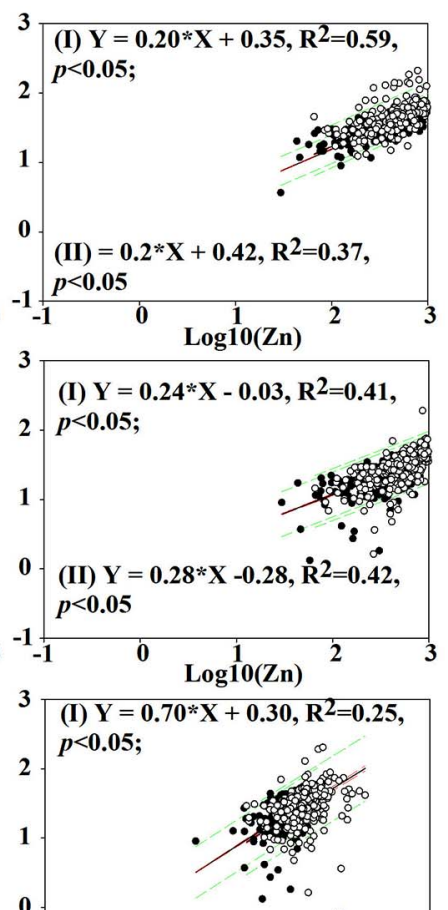

(II) $\mathrm{Y}=0.50 * \mathrm{X}+\mathbf{0 . 6 1}, \mathrm{R}^{2}=0.15$ $p<0.05$

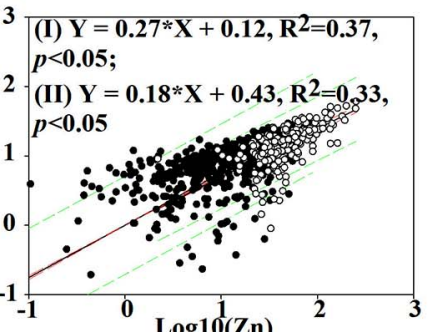

$3 \frac{\log 10(\mathrm{Zn})}{\text { (I) } \mathrm{Y}=0.33 * \mathrm{X}+0.40, \mathrm{R}^{2}=0.42}$ ${ }_{2}<\mathbf{0 . 0 5}$

(II) $\mathrm{Y}=0.25 * \mathrm{X}+0.39, \mathrm{R}^{2}=0.27$,

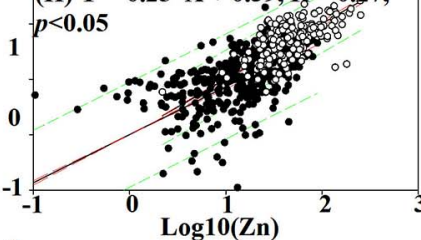

$3 \frac{\log 10(\mathrm{Zn})}{(\mathrm{I}) \mathrm{Y}=0.67 * \mathrm{X}+0.90, \mathrm{R}^{2}=0.31 \text {, }}$ $p<0.05$

2 (II) $=0.67 * \mathrm{X}+0.41, \mathrm{R}^{2}=0.20$,

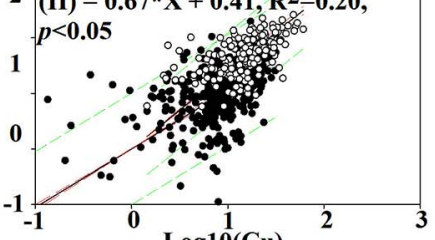

2011 Root middle section
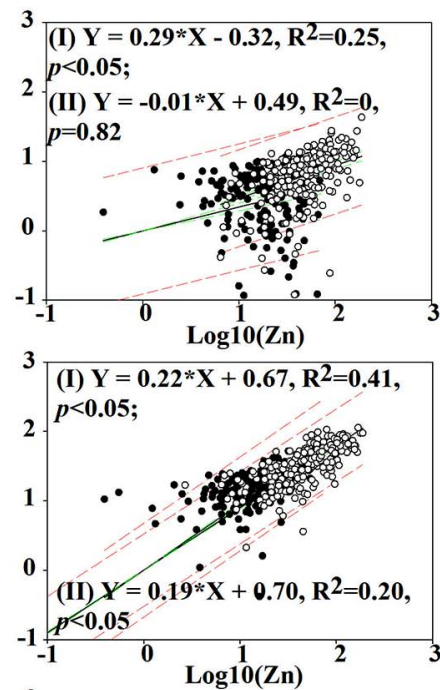

3 (I) $\mathbf{Y}=\mathbf{0 . 2 9} \mathrm{X}+1.29, \mathbf{R}^{2}=\mathbf{0 . 2 0}$

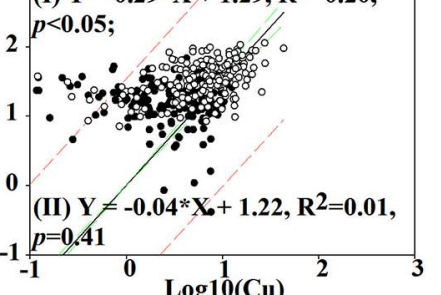



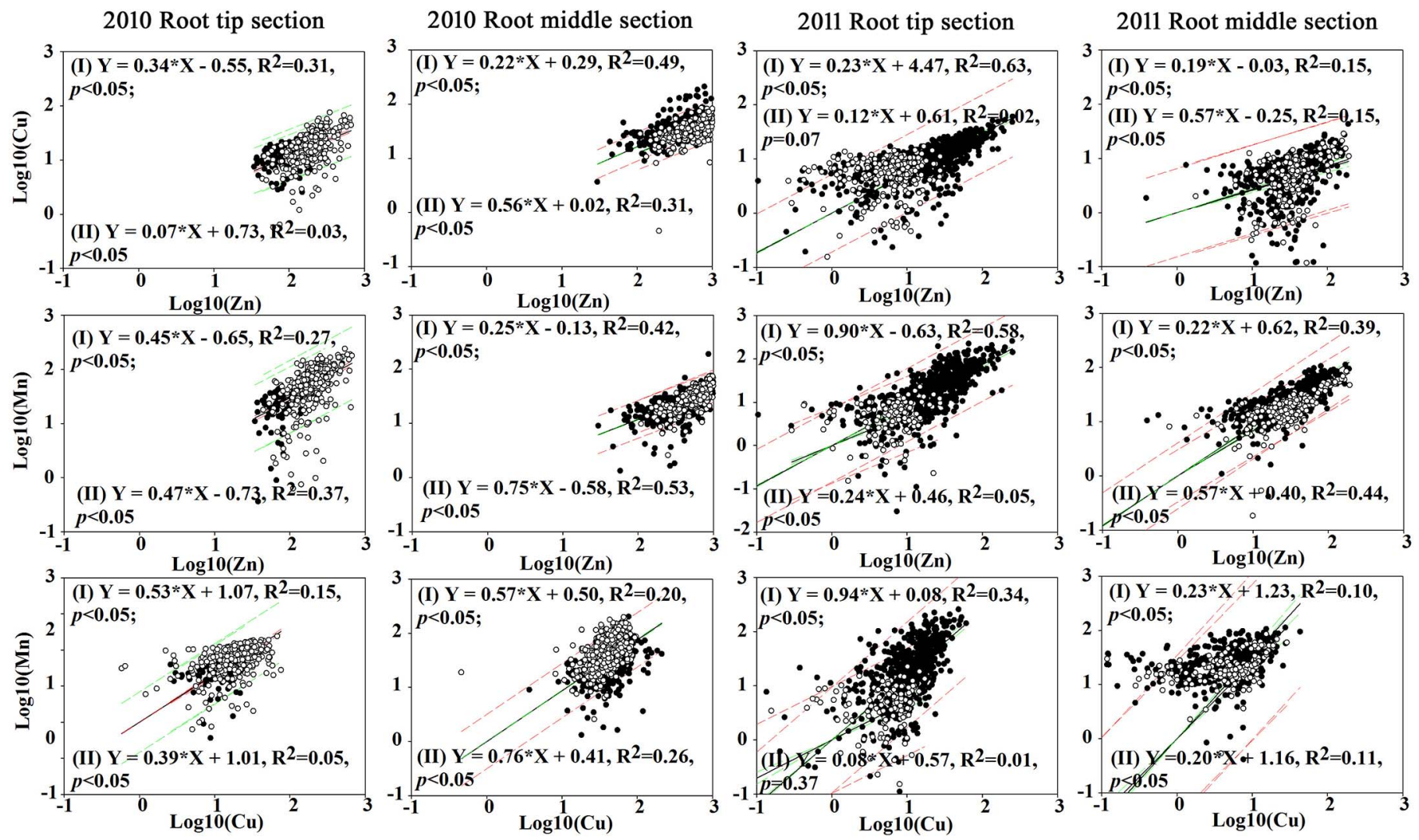

Figure 6

Linear regressions showing relationships between essential nutrients, i.e. Cu versus $\mathrm{Zn}, \mathrm{Mn}$ versus $\mathrm{Zn}$, and $\mathrm{Mn}$ versus $\mathrm{Cu}$ in the dermal tissue and the vascular bundle of T. latifolia L. The plant samples were collected in 2010 and 2011, respectively. Regression line (I) is for the root dermal tissue, and regression line (II) is for the root vascular bundle. Filled circles: root vascular bundle tissue. Open circles: root dermal tissue. Black lines: linear regression lines. Green dashed lines: $95 \%$ confidence level. Red dashed lines: $95 \%$ prediction band.

regression lines between the two types of tissues are only observed in a few cases [Fig. 6(d), 6(h) and 6(l)]. In addition, no distinct boundaries between the scatter plots from the two tissues are observed (Fig. 6). Therefore, the similar relationship of $\mathrm{Zn}, \mathrm{Cu}$ and $\mathrm{Mn}$ between the dermal tissue and the vascular bundles indicate that these three elements accumulated in the two types of tissues possibly follow the same mechanism.

\section{Conclusion}

This study investigated the spatial distributions of $\mathrm{Fe}, \mathrm{Cu}, \mathrm{Mn}$, $\mathrm{Pb}$ and $\mathrm{Zn}$ in T. latifolia $\mathrm{L}$. roots during the growing season to explore possible mechanisms that govern metal localizations in root tissues. In the peripheral dermal tissues, the accumulations of metals in the roots were highly spatially heterogeneous and varied with the root tissue types and the metals themselves. There were significant correlations between the spatial distribution of $\mathrm{Pb}$ and $\mathrm{Fe}$ in the iron-plaque-enriched dermal tissues. At the same time, the correlations between $\mathrm{Cu}$ and $\mathrm{Zn}$ were significant in both iron-plaque-enriched dermal tissue and regular dermal tissues. Moreover, concentrations of $\mathrm{Cu}$ and $\mathrm{Zn}$ were higher in the iron-plaque-enriched dermal tissues, which suggests that iron plaque possibly acts as a barrier of $\mathrm{Pb}$ and a buffer of $\mathrm{Zn}$ and $\mathrm{Cu}$ in metal transport in dermal tissues. In the vascular bundles, significant correlations were observed between the spatial localization of $\mathrm{Zn}, \mathrm{Mn}$ and $\mathrm{Cu}$, especially between $\mathrm{Mn}$ and $\mathrm{Zn}$, indicating the three metals may share similar localization mechanisms in the vascular bundles. Finally, the close association trends between the spatial distribution of $\mathrm{Zn}, \mathrm{Mn}$ and $\mathrm{Cu}$ in the dermal tissues and the vascular bundles suggest that these two types of tissues may accumulate the three elements in a similar mechanism. This study demonstrates that the synchrotron XRF technique can provide an innovative approach to study metal assimilation in plants and explore the mechanism of plant metal uptake and transportation. The results can be used as a reference to advise biological modification of metal uptake and translocation rate of T. latifolia $\mathrm{L}$. from a micro-scale perspective.

\section{Acknowledgements}

This work was supported in part by the China Scholarship Council (YQ) and the Margaret and Herman Sokol Foundation (HF). This project was also supported in part by the US Department of Energy, Office of Science, Office of Workforce Development for Teachers and Scientists (WDTS) under the Visiting Faculty Program (VFP) (HF). Use of the NSLS was supported by the US Department of Energy, Office of Science, Office of Basic Energy Sciences, under Contract No. DE- 
AC02-98CH10886. NSLS X27A was supported in part by the US Department of Energy - Geosciences (DE-FG0292ER14244 to The University of Chicago - CARS). We are also grateful to Dr Steve Heald, Co-editor of Journal of Synchrotron Radiation, and two anonymous reviewers who offered constructive comments and suggestions on an earlier draft of this paper.

\section{References}

Batty, L. C., Baker, A. J. M., Wheeler, B. D. \& Curtis, C. D. (2000). Ann. Bot. 86, 647-653.

Brennan, M. A. \& Shelley, M. L. (1999). Ecol. Eng. 12, 271-297.

Brunham, W. \& Bendell, L. I. (2011). Water Air Soil Pollut. 219, 417428.

Burns, R. \& Burns, R. (2008). Business Research Methods and Statistics Using SPSS. London: SAGE Publications.

Calheiros, C. S., Rangel, A. O. \& Castro, P. M. (2009). Bioresour. Technol. 100, 3205-3213.

Clemens, S., Palmgren, M. G. \& Krämer, U. (2002). Trends Plant Sci. 7, 309-315.

Desouki, S. H. \& Feng, H. (2012). Metal Contamination Sources, Detection and Environmental Impact, edited by H. Shao, pp. 81-94. New York: NOVA Science Publishers.

Dickinson, N. M., Baker, A. J. M., Doronila, A., Laidlaw, S. \& Reeves, R. D. (2009). Int. J. Phytoremediat. 11, 97-114.

EPA (2005). Guidance for Developing Ecological Soil Screening Levels. US Environmental Protection Agency Office of Solid Waste and Emergency Response, Washington, DC 20460, USA.

Feng, H., Qian, Y., Gallagher, F. J., Wu, M., Zhang, W., Yu, L., Zhu, Q., Zhang, K., Liu, C. J. \& Tappero, R. (2013). Environ. Sci. Pollut. Res. Int. 20, 3743-3750.

Feng, H., Qian, Y., Gallagher, F., Zhang, W., Yu, L., Liu, C.-J., Jones, K. W. \& Tappero, R. (2015). J. Environ. Sci. In the press.

French, C. J., Dickinson, N. M. \& Putwain, P. D. (2006). Environ. Pollut. 141, 387-395.

Gallagher, F. J., Pechmann, I., Bogden, J. D., Grabosky, J. \& Weis, P. (2008). Environ. Pollut. 153, 351-361.

Greipsson, S. \& Crowder, A. (1992). Can. J. Bot. 70, 824-830.

Grisey, E., Laffray, X., Contoz, O., Cavalli, E., Mudry, J. \& Aleya, L. (2012). Water Air Soil Pollut. 223, 1723-1741.

Hall, J. L. \& Williams, L. E. (2003). J. Exp. Bot. 54, 2601-2613.

Klink, A., Macioł, A., Wisłocka, M. \& Krawczyk, J. (2012). Limnologica, 43, 164-168.

Liu, J., Leng, X., Wang, M., Zhu, Z. \& Dai, Q. (2011). Ecotoxicol. Environ. Saf. 74, 1304-1309.

Liu, H. J., Zhang, J. L. \& Zhang, F. S. (2007). Environ. Exp. Bot. 59, 314-320.
Luo, X. S., Yu, S., Zhu, Y. G. \& Li, X. D. (2012). Sci. Total Environ. 421-422, 17-30.

Lyubenova, L., Pongrac, P., Vogel-Mikuš, K., Mezek, G. K., Vavpetič, P., Grlj, N., Kump, P., Nečemer, M., Regvar, M., Pelicon, P. \& Schröder, P. (2012). Metallomics, 4, 333-341.

Lyubenova, L., Pongrac, P., Vogel-Mikuš, K., Mezek, G. K., Vavpetič, P., Grlj, N., Regvar, M., Pelicon, P. \& Schröder, P. (2013). J. Hazard. Mater. 248-249, 371-378.

McDonald, J. H. (2009). Handbook of Biological Statistics. Baltimore: Sparky House Publishing.

McKenna, G. F. (1998). Risk-Based Corrective Action and Brownfields Restorations, edited by C. H. Benson, J. N. Meegoda, R. B. Gilbert and S. P. Clemence, pp. 16-29. Geotechnical Special Publication.

McNaughton, S. J., Folsom, T. C., Lee, T., Park, F., Price, C., Roeder, D., Schmitz, J. \& Stockwell, C. (1974). Ecology, 55, 1163-1165.

Marschner, P. (2012). Marschner's Mineral Nutrition of Higher Plants, 3rd ed. New York: Academic Press.

Qian, Y., Feng, H., Zhang, W., Yu, L., Zhu, Q., Zhang, L. \& Wang, X. (2011). Heavy Metal Sediments, edited by L. H. Sanz, pp. 59-85. New York: NOVA Publishers.

Qian, Y., Gallagher, F. J., Feng, H. \& Wu, M. (2012). Environ. Pollut. 166, 23-30.

Rascio, N. \& Navari-Izzo, F. (2011). Plant Sci. 180, 169-181.

Sasmaz, A., Obek, E. \& Hasar, H. (2008). Ecol. Eng. 33, 278284.

Schreiber, L. \& Franke, R. B. (2011). eLS, doi: 10.1002/ 9780470015902.a0002086.pub2.

St-Cyr, L. \& Campbell, P. G. (1996). Biogeochemistry, 33, 45-76.

Taiz, L. \& Zeiger, E. (2010). Plant Physiology. Sunderland, MA: Sinauer Associates.

Tripathi, R. D., Tripathi, P., Dwivedi, S., Kumar, A., Mishra, A., Chauhan, P. S., Norton, G. J. \& Nautiyal, C. S. (2014). Metallomics, 6, 1789-1800.

Tursun, N., Seyithanoglu, M., Uygur, F. N., Elibuyuk, I. O. \& Elibuyuk, E. A. (2011). Flora, 206, 731-735.

Wuana, R. A. \& Okieimen, F. E. (2011). ISRN Ecol. 2011, 1-20.

Yamaguchi, N., Mori, S., Baba, K., Kaburagi-Yada, S., Arao, T., Kitajima, N., Hokura, A. \& Terada, Y. (2011). Environ. Exp. Bot. 71, 198-206.

Ye, Z. H., Baker, A. J. M., Wong, M. H. \& Willis, A. J. (1997). New Phytol. 136, 469-480.

Ye, Z. H., Baker, A. J. M., Wong, M. H. \& Willis, A. J. (1998). Aquat. Bot. 61, 55-67.

Ye, Z. H., Cheung, K. C. \& Wong, M. H. (2001). Can. J. Bot. 79, 314 320.

Zhang, J., Tian, S., Lu, L., Shohag, M. J., Liao, H. \& Yang, X. (2011). J. Hazard. Mater. 197, 264-271.

Zhong, S., Shi, J. \& Xu, J. (2010). J. Soils Sediments, 10, 964-970. 